\title{
International Centre for Diffraction Data (ICDD) welcomes Cambridge University Press as its new publisher for Powder Diffraction
}

ICDD is very pleased to announce that Cambridge University Press is publishing Powder Diffraction. Cambridge now provides copy editing, production, subscription, hosting, and printing services. ICDD will continue to be responsible for the editorial content of the journal utilizing the staff as listed on our masthead. Cambridge University Press has a long history of publishing, and publishes the MRS Bulletin, Microscopy Today, and nearly 300 other journals. We are confident that Cambridge University Press will provide Powder Diffraction an appealing venue in which to grow.

Cambridge University Press publishes over 280 peerreviewed academic journals in a wide variety of subject areas. Their history begins under Henry VIII when in 1534 he granted them letters patent, allowing them to print "all manner of books". They published their first book in 1584, making them the oldest university press in the world. Their reputation grew over the next 400 years based on excellence in scholarly publishing (i.e. academic texts, poetry, and school books) and published such ground-breaking works such as Newton's Principia Mathematica, Milton's Lycidas, Rutherford's Radio-activity, and Chomsky's Language and Mind. They now have over 50 offices across the globe and publish over 40000 titles by authors from over 100 countries.

Powder Diffraction's content is now part of Cambridge's online platform, Cambridge Journals Online (CJO), and we expect to have online content available back to 1986 by the end of 2012. The online issues are more dynamic and feature the ability to "flip" through journal pages like a paper copy, while maintaining the dynamics of html. Users will now use the ScholarOne online peer review and manuscript submission platform to submit manuscripts to Powder Diffraction. We look forward to a mutually beneficial relationship with Cambridge University Press!

Nicole M. Ernst Boris

Managing Editor, Powder Diffraction 